\title{
Front Matter: Volume 11778
}

, "Front Matter: Volume 11778," Proc. SPIE 11778, Relativistic Plasma Waves and Particle Beams as Coherent and Incoherent Radiation Sources IV, 1177801 (7 May 2021); doi: 10.1117/12.2598960

SPIE. Event: SPIE Optics + Optoelectronics, 2021, Online Only 


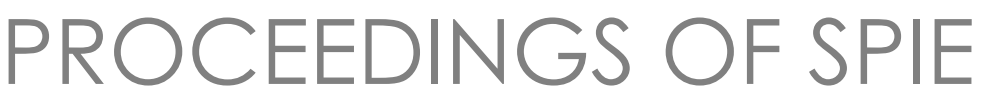

\section{Relativistic Plasma Waves \\ and Particle Beams as Coherent and Incoherent Radiation Sources IV}

Dino A. Jaroszynski

MinSup Hur

Editors

19-23 April 2021

Online Only, Czech Republic

Sponsored by

SPIE

Cooperating Organisations

ELI Beamlines (Czech Republic)

Laserlab Europe

European Optical Society

HiLASE Centre (Czech Republic)

Published by

SPIE

Volume 11778 
The papers in this volume were part of the technical conference cited on the cover and title page. Papers were selected and subject to review by the editors and conference program committee. Some conference presentations may not be available for publication. Additional papers and presentation recordings may be available online in the SPIE Digital Library at SPIEDigitalLibrary.org.

The papers reflect the work and thoughts of the authors and are published herein as submitted. The publisher is not responsible for the validity of the information or for any outcomes resulting from reliance thereon.

Please use the following format to cite material from these proceedings:

Author(s), "Title of Paper," in Relativistic Plasma Waves and Particle Beams as Coherent and Incoherent Radiation Sources IV, edited by Dino A. Jaroszynski, MinSup Hur, Proc. of SPIE 11778 , Seven-digit Article CID Number (DD/MM/YYYY); (DOI URL).

ISSN: 0277-786X

ISSN: 1996-756X (electronic)

ISBN: 9781510643901

ISBN: 9781510643918 (electronic)

Published by

SPIE

P.O. Box 10, Bellingham, Washington 98227-0010 USA

Telephone +1 3606763290 (Pacific Time)

SPIE.org

Copyright @ 2021 Society of Photo-Optical Instrumentation Engineers (SPIE).

Copying of material in this book for internal or personal use, or for the internal or personal use of specific clients, beyond the fair use provisions granted by the U.S. Copyright Law is authorized by SPIE subject to payment of fees. To obtain permission to use and share articles in this volume, visit Copyright Clearance Center at copyright.com. Other copying for republication, resale, advertising or promotion, or any form of systematic or multiple reproduction of any material in this book is prohibited except with permission in writing from the publisher.

Printed in the United States of America by Curran Associates, Inc., under license from SPIE.

Publication of record for individual papers is online in the SPIE Digital Library.

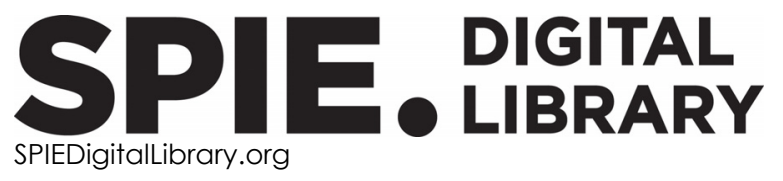

Paper Numbering: A unique citation identifier (CID) number is assigned to each article in the Proceedings of SPIE at the time of publication. Utilization of CIDs allows articles to be fully citable as soon as they are published online, and connects the same identifier to all online and print versions of the publication. SPIE uses a seven-digit CID article numbering system structured as follows:

- The first five digits correspond to the SPIE volume number.

- The last two digits indicate publication order within the volume using a Base 36 numbering system employing both numerals and letters. These two-number sets start with 00, 01, 02, 03, 04, 05, 06, 07, 08, 09, 0A, OB ... 0Z, followed by 10-1Z, 20-2Z, etc. The CID Number appears on each page of the manuscript. 


\section{Contents}

BETATRON, PLASMA UNDULATOR, AND CONVENTIONAL UNDULATOR SOURCES I

1177807 Control of betatron emission via LWFA using aluminum target (Invited Paper) [11778-4]

BETATRON, PLASMA UNDULATOR, AND CONVENTIONAL UNDULATOR SOURCES II

$1177809 \quad$ Controlling the group veloc ity of an intense laser pulse using a pre-pulse (Invited Paper) [11778-6]

TERAHERIZSOURCES

11778 OC Terahert field excitation by a higher-order Gaussian laser pulse propagating in a magnetized plasma (Invited Paper) [11778-9]

$11778 \mathrm{OE} \quad$ Subrelativistic infrared and terahertz pulses from petawatt class laser interaction with complex nanodimensional targets (Invited Paper) [11778-11]

HIGHAED PHYSICS

$11778 \mathrm{OH} \quad$ Probing plasma effects in electron-beam-driven QED cascades (Invited Paper) [11778-13]

11778 0] $\quad$ Electrostatic and scalar fields (Invited Paper) [11778-15]

RAMAN, BRIUOUIN, AND PARAMEIRIC PLASMA PROCESSES

11778 OM Investigations into the volume plasma density grating waveplate (Invited Paper) [11778-18]

APPUCATIONS OF PLASMA ACCEERATORS

11778 ON Foc used beam dosimetry of short VHEE bunches (Invited Paper) [11778-19] 
Proc. of SPIE Vol. 11778 1177801-4 Downloaded From: https://www.spiedigitallibrary.org/conference-proceedings-of-spie on 26 Apr 2023
Terms of Use: https://www.spiedigitallibrary.org/terms-of-use 